\title{
Congress told US ahead, Japan second, rest nowhere
}

\section{Washington}

PrEEMINENCE in the life sciences, abundant venture capital and an entrepreneurial spirit have combined to give the United States a commanding lead in the commercial application of new biotechnological techniques, although Japan will pose a growing challenge. That is the conclusion of a 612-page study of the international biotechnology industry published last week by the Office of Technology Assessment

(OTA),

Congress's science think tank.

The report, Commercial Biotechnology: An International Analysis, predicts that within the next 5-10 years a range of new biotechnological products - including pharmaceuticals, animal vaccines and speciality chemicals - will reach the market. Europe is lagging behind the United States and Japan but a few big chemical and pharmaceutical companies in Britain, France, West Germany and Switzerland may compete strongly in the manufacture of some products.

OTA ascribes the US lead to a number of factors, notably its uniquely favourable tax climate. In 1983 alone, the private sector invested more than $\$ 1,000$ million in the commercialization of biotechnology in the United States, and since 1976 more than 100 new . biotechnology companies have been started up with private venture capital. Underpinning this effort is an enormous investment by the federal government in basic research in biotechnology - some $\$ 500$ million a year compared with about $\$ 60$ million each by Japan, Britain, France and West Germany.

Ready access to venture capital has given the biotechnology industry in the United States a different structure from that of other countries. While its main competitors have depended for the commercialization of biotechnology on established companies, the US effort has been strengthened by a profusion of embryonic companies that have sharpened competition and hastened the spread of expertise from the universities.

But the US lead is not unassailable. OTA believes Japan could catch up if the United States continues to prune funds for basic research in the life sciences and to neglect applied research and bioprocess engineering - the skills that take novel production techniques the laboratory to the factory. Japan has more bioprocess engineers than the United States and spends a bigger slice of its science budget on the solution of applied research problems. Its knack of beating other countries in the race to apply their own basic research could, says OTA, give Japan a bigger share of the biotechnology market than the United States.
What accounts for the United States' present lead? The report says the three most important factors in the competition to commercialize biotechnology are the financial and tax incentives provided by governments, the amount they invest in research and the degree to which they ensure that there are enough well trained experts. In all three areas the United States scores higher marks than its competitors but it cannot afford to be complacent.

The big postwar investment in the basic life sciences has given the United States a competitive edge in the supply of molecular biologists and immunologists, but there may not be enough plant molecular biologists and scale-up experts. Japan, Britain and West Germany, unlike the United States, have invested steadily in generic applied microbiology and bioprocess engineering, areas which will become increasingly important as the industry turns from its present fascination with research and development towards the manufacture of products.

OTA also adds a warning that the dynamism of the newly created biotechnology companies cannot be taken for granted as the industry matures. The existing division of labour between the small companies that have pushed ahead fastest in research and the established companies that have concentrated on marketing and production may break down as the larger companies do more of their own research. And many of the new companies may be unable to raise the money they will need in 5-10 years to move from research to production.

OTA expects the real test of US competitiveness to come when large-scale production begins and bioprocess problems must be faced, initially in pharmaceutical markets. Here the United States will face impressive competition from both Japan and Europe. OTA notes that Britain's major pharmaceutical companies - such as ICI, Glaxo and Wellcome have a great deal of expertise in bioprocessing and that Britain conducts some of the strongest basic research in interdisciplinary plant sciences.

Japanese companies, spurred by government "targeting" of biotechnology, have launched a new drive to enter international pharmaceutical markets. Japanese companies are already world leaders in large-scale plant tissue culture, and the Ministry of International Trade and Industry (MITI) has identified secondary compound synthesis from plants as a major area for commercialization. Unlike the United States, Japanese industry is investing heavily in research on speciality chemical production, an area where Japan is already prominent.
Europe OTA's slight resented

THE Office of Technology Assessment (OTA) report on world biotechnology seriously underestimates Europe's potential, specialists at the European Commission in Brussels were saying last week. "The report puts Europe firmly in third place, with Japan the only competition for the United States", but this overlooks the quality of basic research in Europe according to one official.

Another critic, Dr Mark Cantley, who for two years headed a team investigating the future of biotechnology in Europe as part of the Commission's FAST (Forecasting and Assessment in Science and Technology) investigation, and who is listed as a contributor to the report, says that the last version of the OTA report that he saw was "a relatively messy document", uneven in quality.

A sense of umbrage about the report has been building up in Europe since nearly a year ago, when drafts of the final version first became available. It seems that many European governments were able to persuade OTA to incorporate last minute assessments of the state of biotechnology in their countries. The difficulty seems to have been OTA's reliance on published documents and reports from national contributors rather than on first-hand investigation.

Cantley nevertheless says that OTA is correct in its political judgement of the "difficulty of getting our act together". He illustrates this with the problem of isoglucose in Europe, where a cheap enzymatic method for producing the sugar was effectively vetoed by the sugar-beet lobby. One of Cantley's hopes for the future is that it may be possible to bring about a better integration of agricultural and industrial policy so as to remove impediments to innovation in the agricultural field.

One of Cantley's colleagues, Ken Seargent, noting OTA's dismissivenes of Europe, nevertheless insists that "it need not be like that". He cited both the potential of research in the natural sciences and practical successes such as the pyrethrin analogue insecticide developed in Britain.

Meanwhile, in Brussels, officials were hoping earlier this week that the Commission would agree on Wednesday 2 February to establish a "concertation unit" in biotechnology as a catalyst for more European cooperation in the field. Research commissioner Etienne Davignon is thought to consider this step so important that he will find the money (roughly $\$ 1$ million a year) from within his existing budget, thus avoiding reference to the strife-torn Council of Ministers.

Some in Brussels even consider the new unit as the foundation stone of a European 